\title{
Improving Order-picking Process Through Implementation of Warehouse Management System
}

\author{
Aleksandra Anđelković \\ University of Niš, Faculty of Economics Niš, Serbia \\ Marija Radosavljević \\ University of Niš, Faculty of Economics Niš, Serbia
}

\begin{abstract}
For the purpose of timely response to requests of any participant in the supply chain, as an integral part of every logistics system, warehouse can be found at any place in the supply chain, between suppliers and customers. In that sense, warehouse management involves the control and optimisation of the complex warehouse and distribution system. It might be said that warehousing and inventory management represent support to the production process and strive to complete coordination in relations with all functions, such as marketing, finance, human resources etc. Therefore, any disruption in coordination can cause serious problems throughout the whole business process.

When there is a need for achieving operational efficiency and cost savings, warehouse management and warehouse operations are appropriate areas, in terms of achieving savings which will not jeopardize the quality of products and services. Especially, order-picking, as part of the warehousing process, is one of the most important activities when it is about providing savings. Order-picking process involves taking raw materials/products from a specific location in the warehouse, so as to respond to requirements of production and/or customers. It is estimated that the costs of order-picking participate with $55 \%$ in the total cost of warehousing. However, elimination of this activity can increase the level of dissatisfaction of partners in the supply chain, and, in that way, increase the cost of lost sales. In this regard, one should not consider elimination of orderpicking from the warehousing process as an option, but rather find a way to increase its efficiency.

Due to their flexibility in the order-picking process, people cannot be fully replaced by machines and technologies. However, equipment of order-picking process by the adequate technology could increase efficiency of process and productivity of employees in the warehouse. In that sense, warehouse management system (WMS) is an information technology whose implementation has the aim to increase efficiency of processes performed in warehouse. Therefore, the aim of the paper is to emphasize the importance of implementing a warehouse management system for improving the order-picking process, as warehouse activity. In order to accomplish this aim, empirical research has been conducted. A random sample of companies specialized for performing distribution activities has been chosen. The authors of the paper have analysed which segment of order-picking process can achieve maximum benefits from implementation of this technology, but also whether there are any limitations in terms of implementation of WMS. Based on the statistical methods (descriptive statistics and cluster analyses), through the SPSS software package, the results presented in the paper indicate the segments of order-picking process which are mostly improved by implementing the WMS, as information technology.
\end{abstract}

\section{Keywords}

Warehouse, process, warehouse management system, order-picking.

\section{Introduction}

Warehouse is very important for every company, especially for production and retail sector, but also for the whole supply chain. Term warehouse is often mentioned in a negative context, as the cause of high costs and waste of time, without adding value to the product. Such understanding 
of warehouse and warehousing process is limited and does not observe the key tasks of warehouse management, such as: reducing the warehouse cost and holding inventory, increasing efficiency, increasing accuracy, increasing productivity while achieving greater value for customers and higher levels of service quality (Richards, 2014, 5). According to the list of tasks one can conclude that warehousing could be used as a source of competitive advantage.

Modern market conditions include increasing customer's power, and their greater and different requirements in terms of quality, but also faster and accurate delivery. Therefore, fast and accurately delivery could be used by companies and supply chains as a way of increasing competitive advantage (Yu, 2008, p. 2). But, fast and accurate reaction of companies or supply chains need appropriate warehouse system and capacity. Beside this, customer needs are characterized by reduction of order sizes and increase of frequencies of order. For this reason, companies need to keep inventories on the low level, with a possibility of variety of products for satisfying customers' needs. Also, in modern supply chains, warehouses and warehousing process are characterized by centralisation of facilities (Christopher, 2016). This is the way for reducing warehouse costs and decreasing inventory level. But, at the same time, this is a challenge for warehousing, in terms of providing higher level of service quality and larger product variety.

These trends are challenges for order-picking, as segment of warehousing process. Orderpicking process implies retrieving individual raw materials and/or products from certain location at the warehouse, with the purpose of fulfilling customer orders. So, order-picking could be a factor of fast and accurate delivery, and a high level of service quality. Order-picking, as labour-intensive warehousing operation, involves checking the availability of raw materials and/or products, assembling documents, defining the schedule for preparing orders and transportation. This operation could be very capital-intensive in situations when warehouse is automated (De Koster, LeDuc, \& Roodbergen, 2007).

Costs of order-picking are result of the following activities: travelling (55\%), searching (15\%), extracting (10\%) and paperwork (20\%) (Karasek, 2013, p. 115), and the share of order-picking cost in total warehouse cost is about 55\% (Fumi, Scarabotti, \& Schiraldi, 2013; Tompkins, White, Bozer, \& Tanchoco, 2003). The high share of or- der-picking costs within the structure of warehouse costs indicates that this segment of warehousing process could be used for increasing efficiency and improving warehousing process. This is the reason why researchers and practitioners have recognized order-picking process as part of warehousing, which needs to be continuously improved.

Development of information technology and its implementation in warehouse, contribute to the fact that this logistics activity becomes more competitive. In that sense, warehouse management system, as an information technology, could be used for improving order-picking process, in context of minimizing cost and time for orderpicking, and achieving higher level of service quality and competitiveness.

\section{The importance of improving order-picking process}

Warehouse operations are critical for each supply chain. According to some authors (Rouwenhorst et al., 2000), the efficiency and effectiveness of the supply chain network depends from warehousing operations and its performances. Through warehousing operations, supply chains are able to answer the ever changing market conditions and uncertainty of demand fluctuations (Kim, Bahr, \& Leung, 2013, p. 414).

High warehouse costs in total logistics costs indicate importance of managing and optimizing of the warehousing process. According to different studies, warehousing costs (operating and capital) amount to about $23 \%$ of total logistics costs in the United States (Baker \& Canessa, 2009, p. 426), while in Europe these costs account for $39 \%$ of total logistics costs (Fumi, Scarabotti, \& Schiraldi, 2013).

Warehousing process includes receiving, putting away, storage, order-picking and dispatching of raw materials/products (Berg \& Zijm, 1999; Kim, Bahr, \& Leung, 2013). Order-picking is one of the most important activities in the warehouse. This warehouse activity includes retrieving raw materials and/or products from the warehouse at the request of the customer (Moellera, 2011, p. 178; Tompkins et al. 2003; Đukić, Česnik, \& Opetuk, 2010), or presents a process of gathering raw materials or products which are prepared according to some customer orders (Reif, Gunthner, Schwerdtfeger, \& Klinker, 2010). Order-picking involves defining a sequence of visiting the specific locations in warehouse space where each part of order is stored, according to the model of trav- 
elling salesman (Daniels, Rummel, \& Schantz, 1998). Also, this process could be defined as consolidation of one or more ordered items.

Order-picking is the most laborious and the most costly activity in warehouse (Đukić, Česnik, $\&$ Opetuk, 2010). This process has a direct influence on speed of delivery, and on the level of customer services. So, each company in the supply chain needs to strive for reducing time of orderpicking activity and for improving order-picking efficiency.

Importance of order-picking process derives from facts that this warehousing operation requires the most resources, and is the most customer-sensitive (Miller, 2004). Importance of this process is greater because this is the last process before delivering orders, so possible mistakes could have a great influence on quality of delivery, and future relationships with customers and their satisfaction.

Designing of order-picking system is very complex task, because of close relationship between facilities, organisational structure and information management (Hompel \& Schmidt, 2007 , p. 30). Manufacture's trends - smaller lotsizes, point-of-use delivery, postponement and customisation of product, reduction of cycle time, as well as distribution trends - accepting late orders, rapid and timely delivery have made orderpicking more an important and complex process (De Koster, Le-Duc, \& Roodbergen, 2007).

The main factors which determine efficiency of order-picking process are: demand for raw materials/products, the warehouse layout, location of the items, the picking method in combination with the routing methods, experience and knowledge of employees, as well as the level of automation of warehouse (Gattorna, 1997). Although the last one is very important, sometimes companies, due to the high cost of order-picking process automation, are forced to use manual operation at the expense of efficiency and time.

Experiences from practice have shown that half of warehouse costs arise from the orderpicking process (Tompkins et al., 2003). The basic reasons for this situation are complexity and labour-intensity of order-picking process. Orderpicking depends from labour, and also cost and productivity of this operation. Completely automated warehouse and its efficiency and accuracy are dependent from labour (Miller, 2004).

The one of the major objectives of orderpicking is maximizing the level of service quality by available resources (labour, equipment, capi- tal). Service quality level depends on a lot of factors as variation of order delivery time, order integrity, and accuracy. Faster order-picking operations have influence on service quality level, because faster order of retrieving means faster delivery to the customer. Also, minimising of the total costs is the one of the most important objectives of order-picking process. Other objectives of order-picking process are (De Koster, Le-Duc, \& Roodbergen, 2007):

- minimising the throughput time of an order,

- minimising the overall throughput time,

- maximising the use of space,

- maximising the use of equipment,

- maximising the use of labour,

- maximising the accessibility to all items.

Optimisation of order-picking process includes optimisation of duration of the following phases (Broulias, Marcoulaki, Chondrocoukis, \& Laios, 2005, p. 20):

1. travel time required for the picker to reach the pick point,

2. search time required for the products to be found,

3. retrieval time required for the products to be retrieved, and

4. return time required for the picker to transport the products to the order point.

Different methods of order-picking, equipment or information technology could be used for improving order-picking process. It is well known that implementation of Warehouse Management System (WMS) means integration in day-to-day planning and controlling processes. This software system presents a great support to warehousing process. Before WMS companies were using Inventory Control System. But WMS has greater results in terms of functionality and optimisation routines (Moellera, 2011, p. 178). When its usage started, WMS was considered important for providing information of materials/products warehouse location, but today this is a complex and advance technology with main goal efficiently control of all items within the warehouse. The primary functions of WMS may be summarized in this way (Inoday consultancy services pvt., 2016):

- minimizes the paperwork and write off,

- fully integrated tool - organization can make the connection between two different systems, 
- picking, packing and shipping services,

- lots/serial/expiry management,

- multi-carrier shipping toolkit.

The basic purpose of WMS is managing the warehouse. Advantages of WMS could be used for keeping record of warehouse capacity (location management), looking to stored units (inventory management) and optimizing warehouse activities (Hompel \& Schmidt, 2007, p. 46). WMS could be an appropriate factor of improving productivity and efficiency of all process in warehouse. Also, implementation of WMS contributes to planning and controlling order-picking process with the purpose of increasing its productivity and optimisation. Implementation of WMS could be way for solving following problems (Inoday consultancy services pvt., 2016):

- manually tasks and errors as well,

- late invoices and shipments,

- not proper information of inventory control,

- storage location of materials or products is not fixed.

Importance of implementation of WMS is reflected on facilitating and speeding up of product tracing. Expectations from implementation also include significant reduction of search time, which is over a $30 \%$ of total order-picking time. (Broulias et al., 2005). Implementation of WMS creates possibilities for developing a green warehouse or distribution centre. For example, implementation of WMS creates opportunities for a green warehouse by reducing paper consumption. By implementation of WMS each company could reduce overall warehouse costs through the optimisation of activities. Optimising activities by using transportation equipment, according to WMS requirements, could contribute to reducing energy consumption and $\mathrm{CO}_{2}$ emission.

It is true that a lot of elements of warehouse are designed before application WMS, as warehouse layout, selection of handling and warehouse equipment, methods and procedures of orderpicking process, and that it could be a great problem for later implementation WMS (Benson, 2013). However, WMS is not equally important and needed for all companies. For example, WMS is particularly important for companies which sell their products through the Internet, or serve a huge number of customers and/or consumers, or have a large number of disparate products in their assortment. In the above mentioned examples, it is more difficult to carry out order-picking process, and that is the reason why the implementation of WMS is more important.

Table 1 Effects of WMS implementation on order-picking process

\begin{tabular}{|l|l|}
\hline \multicolumn{1}{|c|}{ Benefits } & \multicolumn{1}{c|}{ Indicators } \\
\hline \multirow{5}{*}{ Informational } & Increased data accuracy \\
\cline { 2 - 2 } & $\begin{array}{l}\text { Improved information sharing } \\
\text { between supply chain partners }\end{array}$ \\
\cline { 2 - 2 } & $\begin{array}{l}\text { Better determining of arrival } \\
\text { and despatch times }\end{array}$ \\
\hline \multirow{5}{*}{ Operational } & Reduced material handling \\
\cline { 2 - 2 } & Faster exception management \\
\cline { 2 - 2 } Raw materials/Product & Quality control \\
\cline { 2 - 2 } related & $\begin{array}{l}\text { Supply and production conti- } \\
\text { nuity }\end{array}$ \\
\cline { 2 - 2 } & Better customer services \\
\cline { 2 - 3 } & Reduced labour \\
\cline { 2 - 2 } & Lower costs \\
\hline \multirow{5}{*}{ Reduced shrinkage } \\
\cline { 2 - 2 } & $\begin{array}{l}\text { Raw materials/Product track- } \\
\text { ing }\end{array}$ \\
\cline { 2 - 2 } & Space utilisation \\
\cline { 2 - 2 } & Reduced stockouts \\
\cline { 2 - 2 } & Lower inventory \\
\hline
\end{tabular}

Source: Kim et al., 2013, 414

Table 1 presents different indicators of benefits after implementation of WMS. All indicators are classified at three groups of benefits: informational, operational, and raw materials/product related benefits. With the purpose of analyzing the WMS implementation importance for orderpicking, the authors have used the indicators from Table 1. For analyzing the importance of implementation of WMS technology for order-picking process, the following hypotheses are defined:

H1: Implementation of WMS in the warehouse contributes to improving the order-picking process, in terms of informational, operational and raw materials/products related benefits.

$\mathrm{H} 2$ : Benefits of WMS implementation are more evident in the companies that have greater number of clients (customers and/or consumers).

\section{Research methodology}

Analysis of benefits, as the results of WMS implementation is necessary for justification of the improvement of order-picking process. This analysis is important, since order-picking process is significant factor of competitive advantage, in sense of lead time and cost of order-picking. Long lead time of order-picking process influences the delivery delay, which can be transferred through 
domino effect to other partners of the supply chain. Also, the high cost of order-picking is a factor of product price, and leads to consumer dissatisfaction, especially those which are priceoriented. Mentioned problems may be solved through the information technology, such as WMS.

In order to test the research hypotheses, empirical research was conducted in November and December 2016. Companies specialised in warehouse activities were in the research focus, due to the fact that order-picking process performs into warehouse. According to that, the survey questionnaires were sent to the managers of distribution centres on the territory of the Republic of Serbia. The total number of sent questionnaires was 114 , while the number of responses was 34 . Thus the response rate is $29.82 \%$.

The sample includes 21 small and medium enterprises (SME) (62\% of the sample) and 13 large companies ( $28 \%$ of the sample), and considering the origin of the capital, 8 companies have foreign origin of the capital (24\%). Also, some of the observed companies have not implemented the WMS yet $(20 \%$ of the companies in the sample are those that have not yet implemented the WMS). The questionnaire consists of two groups of questions. The first group is concerned with general questions about the company (name and headquarters of the company, number of employees, the origin of capital, legal form, revenue, and number of customers). The second part of the questionnaire is made up of specific questions concerning the implementation of WMS within warehouses and assessment of benefits which are results of WMS implementation. Respondents (warehouse managers) were asked to express their opinion and give marks according to effects of implementation WMS on order-picking process (marks vary from 1 to 5 , where 1 means the lowest mark and 5 means the highest mark).

In the process of researching and hypotheses testing, the authors used statistical methods. Beside the descriptive statistics (mean value, standard deviation and variance), cluster analysis was used, for grouping objects of research in homogeneous groups. Forming a group of objects should show high internal homogeneity or similarity within the cluster and high external diversity or between clusters (Chakrapani, 2006, p. 59). Cluster analysis is used as an objective methodology for classifying. Authors used a hierarchical method and the centroid method for determining distances.

\section{Results and discussion}

The authors of the paper use descriptive statistics as a way of assessing the benefits of implementation of WMS in the sense of improving process of order-picking according to the surveyed managers. Descriptive statistics (Table 2) shows how managers assess individual segments of orderpicking after the implementation of WMS. The largest contribution of WMS has been reflected in Lower inventory (4.8824). The implementation WMS was the least useful, according to the managers' opinion, for providing Reduced labour (1.6765). According to the managers, the number of employees has not decreased since the employees are not assigned to other jobs. Among the benefits, the best results from WMS implementation are recorded for the group Raw materials/Product related benefits. The largest discrepancy between the managers in terms of contribution of WMS exists in Better customer services (standard deviation is 1.34873), while they agreed concerning Lower inventory (standard deviation is 0.32703 ). For all variables except for Better determining of arrival and despatch times, Reduced material handling, Reduced labour and Reduced shrinkage average marks are higher than 3 . These results show that managers positively assessed the importance of WMS for improving the orderpicking process and recognized the benefits of implementation this software solution.

Table 2 Descriptive Statistics

\begin{tabular}{|l|c|c|c|c|}
\hline & $\mathbf{N}$ & Mean & $\begin{array}{c}\text { Std. } \\
\text { Deviation }\end{array}$ & Variance \\
\hline $\begin{array}{l}\text { Increased data } \\
\text { accuracy }\end{array}$ & 34 & 3.4412 & 1.07847 & 1.163 \\
\hline $\begin{array}{l}\text { Improved infor- } \\
\text { mation sharing } \\
\text { between supply } \\
\text { chain partners }\end{array}$ & 34 & 3.0294 & .96876 & .939 \\
\hline $\begin{array}{l}\text { Better determin- } \\
\text { ing of arrival and } \\
\text { despatch times }\end{array}$ & 34 & 2.5882 & 1.10420 & 1.219 \\
\hline $\begin{array}{l}\text { Reduced mate- } \\
\text { rial handling }\end{array}$ & 34 & 2.9412 & 1.15316 & 1.330 \\
\hline $\begin{array}{l}\text { Faster exception } \\
\text { management }\end{array}$ & 34 & 3.3824 & 1.18103 & 1.395 \\
\hline Quality control & 34 & 3.7059 & 1.33778 & 1.790 \\
\hline $\begin{array}{l}\text { Supply and pro- } \\
\text { duction continuity }\end{array}$ & 34 & 3.2353 & 1.12973 & 1.276 \\
\hline $\begin{array}{l}\text { Better customer } \\
\text { services }\end{array}$ & 34 & 3.3824 & 1.34873 & 1.819 \\
\hline Reduced labour & 34 & 1.6765 & .76755 & .589 \\
\hline Lower costs & 34 & 3.8824 & .97746 & .955 \\
\hline $\begin{array}{l}\text { Reduced } \\
\text { shrinkage }\end{array}$ & 34 & 2.9412 & .95159 & .906 \\
\hline
\end{tabular}




\begin{tabular}{|l|c|c|c|c|}
\hline $\begin{array}{l}\text { Raw } \\
\text { materials/Product } \\
\text { tracking }\end{array}$ & 34 & 4.4706 & .61473 & .378 \\
\hline Space utilisation & 34 & 3.4412 & 1.02073 & 1.042 \\
\hline $\begin{array}{l}\text { Reduced } \\
\text { stockouts }\end{array}$ & 34 & 3.6765 & 1.06517 & 1.135 \\
\hline Lower inventory & 34 & 4.8824 & .32703 & .107 \\
\hline Valid N (listwise) & 34 & & & \\
\hline
\end{tabular}

Source: The authors

All companies from the random sample are divided into two clusters by Cluster analysis. According to Table 3 and clusters average marks it can be concluded that the first cluster is made up of companies which have lower marks for benefits from the WMS implementation in relation to the other cluster. After examining the affiliation of clusters, it can be seen that all companies from the first cluster belong to the SME category. This could be explained by the fact that SMEs, considering limited resources, are not able to realize the full benefits from the implementation of WMS.

Table 3 Final Cluster Centres

\begin{tabular}{|l|c|c|}
\hline \multirow{2}{*}{} & \multicolumn{2}{|c|}{ Cluster } \\
\cline { 2 - 3 } & $\mathbf{1}$ & $\mathbf{2}$ \\
\hline Increased data accuracy & 2.84 & 4.20 \\
\hline $\begin{array}{l}\text { Improved information sharing between } \\
\text { supply chain partners }\end{array}$ & 2.84 & 3.27 \\
\hline $\begin{array}{l}\text { Better determining of arrival and despatch } \\
\text { times }\end{array}$ & 2.00 & 3.33 \\
\hline Reduced material handling & 2.32 & 3.73 \\
\hline Faster exception management & 2.58 & 4.40 \\
\hline Quality control & 2.79 & 4.87 \\
\hline Supply and production continuity & 2.79 & 3.80 \\
\hline Better customer services & 2.63 & 4.33 \\
\hline Reduced labour & 1.53 & 1.87 \\
\hline Lower costs & 3.63 & 4.20 \\
\hline Reduced shrinkage & 2.53 & 3.47 \\
\hline Raw materials/Product tracking & 4.42 & 4.53 \\
\hline Space utilisation & 2.95 & 4.07 \\
\hline Reduced stockouts & 2.95 & 4.60 \\
\hline Lower inventory & 5.00 & 4.73 \\
\hline
\end{tabular}

Source: The authors

According to Table 4, the first cluster has 19 companies from the tested sample. Only two companies from group of the SME has found into second cluster. By calculating the average marks of benefits from WMS implementation in large companies and SMEs, significant difference could be noticed. The average mark of improvement of order-picking process by WMS implementation in large companies is 3.987615 , while this result for
SME's is 3.003175 . These marks are also confirmation of cluster analysis results.

Table 4 Number of Cases in each Cluster

\begin{tabular}{|l|c|c|}
\hline \multirow{2}{*}{ Cluster } & 1 & 19.000 \\
\cline { 2 - 3 } & 2 & 15.000 \\
\hline Valid & 34.000 \\
\hline Missing & 0.000 \\
\hline \multicolumn{2}{|c|}{ Source: The authors }
\end{tabular}

In order to analyse the relationship between benefits from the implementation of WMS for improving order-picking process and number of company's partners, the authors used the Pearson Chi-Square test. Most of the companies in the first cluster have a smaller number of users/partners (up to 10). Application of Pearson Chi-Square test showed a relationship and justification of the second hypothesis. The value of Pearson Chi-Square test $(10.482)$ and $\mathrm{p}$ value less than $0.05 \mathrm{p}=$ $0.005)$ confirm the second hypothesis, that the benefits from WMS for improving order-picking process depends from number of partners.

\section{Conclusion}

It is beyond doubt that process of order-picking is very significant in terms of contribution to the competitiveness of company. However, this part of warehouse could be used as a source of competitiveness in terms of providing a higher level of service quality, but also in terms of minimizing costs. In the first case order-picking process is used for customers' needs that are business oriented, and for the second case focus is on priceoriented customers. In any case, the functioning of order-picking process depends on information technology, such as WMS.

Empirical research results show that managers confirm high contribution of WMS for improving order-picking process. However, the results also show that $90 \%$ of companies from the first Cluster are SME. Taking into account that this group of tested sample is limited in terms of lack of material and immaterial resources, it could be possible, that this is the key reason why this group of companies could not get maximum benefits from WMS. Also, the reasons could include insufficient number of employees, employees that are inadequately trained for using WMS, lack of funds for maintenance of the software, and use of incomplete software solutions. Moreover, in some situations it is not justified to use WMS. One such situation is a small number of partners, i.e. when 
the warehouse or distribution centre serves a small number of users. In addition, case studies have shown that implementation of the WMS system does not give positive results in all cases in large companies, especially if the hardware is not in accordance with the installed software. For example, in 1993, Adidas tried to implement WMS (combination of WMS from two different producers). The system just did not work (Supply Chain Digest, 2006, p. 6). In 1996, Adidas was able to respond only to $20 \%$ of total orders in North America. For several months system was not able to reach its full speed. The results were huge losses of the Company (Supply Chain Digest, 2006, p. 6).

Anyway, the research whose results are presented in this paper could be observed as a pilot study. It points out the need for further analysis of the importance and contribution of WMS to orderpicking process and warehousing. In addition, results of the research could be used as a basis for examining other factors which also could be a limitation in terms of providing the WMS benefits, such as serving one or a small number of markets, a narrow assortment for warehousing, etc. sm

\section{References}

Baker, P., \& Canessa, M. (2009). Warehouse design: a structured approach. European Journal of Operational Research , 193 (2), 425-436.

Benson, D. (2013). WMS and Picking. We Are The Practitioners. Retrieved March 1, 2017 from http://www.wearethepractitioners.com/library/thecontributors-voice/2013/04/03/wms-and-picking

Berg, J. P., \& Zijm, W. H. (1999). Models for warehouse management: Classification and examples. International Journal of Production Economics , 59 (13), 519-528.

Broulias, G. P., Marcoulaki, E. C., Chondrocoukis, G. P., \& Laios, L. G. (2005). Warehouse Management for Improved Order Picking Performance: An Application Case Study From the Wood Industry. In C. Papadopoulos, Proceedings of the 5th International Conference on Analysis of Manufacturing Systems Production Management (pp. 17-23).

Chakrapani, C. (2006). Statistics in Market Research. London: Arnold Publishers.

Christopher, M. (2016). Logistics \& Supply Chain Management (5th ed.). New York: Financial Times.

Daniels, R. L., Rummel, J. L., \& Schantz, R. (1998). A model for warehouse order picking. European Journal of Operational Research , 105 (1), 1-17.

De Koster, R., Le-Duc, T., \& Roodbergen, K. J. (2007). Design and control of warehouse order picking: a literature review. European Journal of Operational Research , 182 (2), 481-501.

Đukić, G., Česnik, V., \& Opetuk, T. (2010). Order-picking Methods and Technologies for Greener Warehousing. Strojarstvo , 52 (1), 23-31.

Fumi, A., Scarabotti, L., \& Schiraldi, M. M. (2013). The Effect of Slot-Code Optimization in Warehouse Order Picking. International Journal of Engineering Business Management , 5 (20), 1-10.

Gattorna, J. (1997). Handbook of Logistics and Distribution management. London: Gower Publisher Company.

Hompel, M., \& Schmidt, T. (2007). Warehouse Management: Automation and Organisation of Warehouse and Order Picking Systems. New York: Springer.

Inoday consultancy services pvt. Ltd. . (2016). Web and software application development. Retrieved March 2, 2017 from inodayservices.blogspot.rs: http://inodayservices.blogspot.rs/2016/02/howorganizations-can-make-strategies.html

Karasek, J. (2013). An Overview of Warehouse Optimization. International Journal of Advances in Telecommunications. Electrotechnics , 2 (3), 111-117.

Kim, K. M., Bahr, W., \& Leung, S. C. (2013). RFID in the Warehouse: A Literature Analysis (1995-2010) of its Applications.Benefits, Challenges and Future Trends. International Journal of Produciton Economics , 145 (1), 409-430.

Miller, A. (2004). Order Picking for the 21st Century: Voice vs. Scan Technology. Retrieved March 2, 2017 from Manufacturing \& Logistics IT Magazine: http://www.logisticsit.com/absolutenm/articlefiles/688voice_vs_scanning.pdf

Moellera, K. (2011). Increasing warehouse order picking performance by sequence optimization. Procedia Social and Behavioral Sciences , 20, 177-185.

Reif, R., Gunthner, W. A., Schwerdtfeger, B., \& Klinker, G. (2010). Evaluation of an Augmented Reality Supported Picking System under Practical Conditions. Computer Graphics Forum , 29 (1), 2-12.

Richards, G. (2014). Warehouse Management. London: KoganPage.

Rouwenhorst, B., Reuter, B., Stockrahm, V., Van Houtum, G. J., Mantel, R. J., \& Zijm, W. H. (2000). Warehouse design and control: Framework and literature review. European Journal of Operational Research , 122, 515533.

Supply Chain Digest. (2006). The 11 Greatest Supply Chain Disasters. Retrieved March 2, 2017 from Supply Chain Digest: http://scdigest.com/assets/reps/SCDigest_Top11-SupplyChainDisasters.pdf

Tompkins, A. T., White, J. A., Bozer, Y. A., \& Tanchoco, J. M. (2003). Facilities Planning (3rd ed.). Hoboken: John Wiley \& Sons.

Yu, M. (2008). Enhancing Warehouse Performance by Efficient Order Picking. Rotterdam: Erasmus University. 


\section{Correspondence}

\section{Aleksandra Anđelković}

Faculty of Economics Niš

Trg kralja Aleksandra Ujedinitelja 11, 18000, Niš, Serbia

E-mail: aleksandra.andjelkovic@eknfak.ni.ac.rs 